\title{
Mundus Mulieris: A Number Of Issues Related To The Position Of Women In Rome
}

Alicia Valmaña Ochaíta, Ph.D., University of Castilla-La Mancha, Spain

\begin{abstract}
Women in Rome always took a back seat to the men; in fact and law, the woman was subordinate to her husband, or pater; she was subject to perpetual tutelage and had no political rights. The fact that right from the beginning, the roman family was not based on blood ties but rather on the common bond of being subject to the authority of a pater familias determined the place of women both in the family and within society. However, this element of potestas which kept the agnatic family together and meant that it was regarded as such, evolved alongside the changes in the way in which the family was understood and therefore, affected the legal status of those subject to the power of the pater, specifically, that of women. Indeed, over the course of the roman Republic, particularly towards the end, this situation of total incapacity of women began to crumble due, to a great extent, to the economic position of some of them and to their social status. Thus, by way of praxis, roman women gradually gained access to a certain level of autonomy.
\end{abstract}

Keywords: Women; Rome; Ostentation; Feminine Virtues; Sumptuary Laws

\section{MUNDUS MULIERIS AND OTHER "MUNDUS"*}

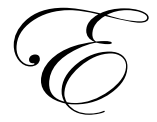

rnout-Meillet, s.v.mundus, point to the existence of two or three different words in relation to mundus: an adjective (elegant) and a noun (adornment and world); Festus identifies the two meaningsadornment and world- deriving from mouere: mundus appellatur caelum, terra, mare et aer. Mundus etiam dicitur ornatus mulieris, quia non alius est quam quod moveri potest. Mundus quoque appellatur lautus et purus $(125,21$, L.) "the sky, earth, sea and air are termed mundus. The adornment of women is also termed mundus since it is nothing more than that which can be moved. Mundus also means clean and pure". It would appear that the etymology based on mouere accounts not only for objects which a woman would usually wear, but also those which can be easily carried. Varro, however, states that mundus ornatus muliebris dictus a munditia (the so-called mundus, personal adornment of women), is derived from munditia (pulcritud) (de lingua latina, V, 129, based on the translation into Spanish by L.A. Hernández Miguel).

The expression mundus mulieris (Ulpianus) is mentioned in D.,34, 2, 25, 10 1 , under a section devoted to the legacies of gold, silver, ornaments, perfumes and ointments, of dresses and wardrobe and of statues. Specifically, it refers to the everyday objects used by women in their personal hygiene and grooming -Mundus mulieris est, quo mulier mundior sit- and which, together with jewels, are used for their beautification.

The quantity and variety of objects that have survived to the present day reveal that this mundus mulieris was, without doubt, substantial. The archaeology, paintings, sculptures, literary and legal sources provide ample evidence to support this notion: the archaeology suggests that household cosmetics production was a growth industry, driven by the importation of prized ingredients. Incredibly, some of these have been found in recent times, having survived through the centuries (D’Ambra, 2007, page 115). Roman women, particularly those with a certain

\footnotetext{
${ }^{*}$ This work forms part of a wider study which is awaiting publication. Traslated into English by Adam Collins.

${ }^{1}$ References with D., are from the Digest of Justinian.
} 
status, habitually used these cosmetic products; these same sources, disregarding the mysoginistic element which may be behind many of them, continually refer to the cultus and the ornatus, the everyday beautification of the roman woman (Livy, 34, 7, 9; Tertulianus (de cult fem.1,4); or even Ovid, who devotes a work to female beautification, vide Pociña A. and López, A., 1977, 1-27). Also of interest, as always, are the Plautine references: with regard to a passage from Poenulus, García Jurado (1993, page 43ff) highlights Plautus' mysoginistic criticism of women of the lowest social status, the prostitutes (and by extension, the matrons), when they complain of the effort required to carry out their personal hygiene and grooming. It is evident that women moved in a world where personal grooming jewels and wardrobe not only occupied a substantial part of their time (D'Ambra, 2007, page 114ff and García Jurado, 1994, page. 72ff) but also reflected their social and economic status.

It is precisely the question of the economic position of women during the last centuries of the Republic which leads to the passing of a large number of laws. The lex Oppia of 214 B.C. forbade excessive luxury to women; falling within other sumptuary laws aimed at avoiding the ostentation of riches (such as the Lex Aemilia of 115 B.C. which regulated the kinds of food which could be served at banquets). Again, Plautus gives us an insight, in the form of critical satire, into the reality at the time of the lex Oppia:

enim mihi quidem aequomst purpuram atque aurum dari,

ancillas, mulos, muliones, pedisequos,

salutigerulos pueros, vehicla qui vehar" (Aulularia, 500-502)

a phrase which the elderly Megadoro puts in the mouth of a rich woman who demands from her husband, among other things, purple robes, golden jewels and carriages. References to the requirements of the lex Oppia are frequently supported by the doctrine which specifically addresses the prohibition of purple clothing, the use of gold and carriages (Culhman, 1982, pages 786-787 and García Jurado, 1993, page 41ff). The character defends the fact that men married poor women rather than rich women because by doing so, there would be less envy in the city, they would command greater respect from the women and men would spend less:

et multo fiat civitas concordior,

et invidia nos minore utamur quam utimur,

et illae malam rem metuant quam metuont magis,

et nos minore sumptu simus quam sumus.

in maximam illuc populi partem est optimum (Aulularia, 480-485)

Plautus' text provides a valuable testimony not only of the purpose of the lex Oppia - to avoid the exteriorization of excessive luxury, which was causing social problems (Agati Madeira, 2004, page 92)-, but also of the reality behind the existence of many rich women who, accustomed to having and spending as desired, were also demanding- Nunc quoquo venias plus plaustrorum in aedibus/videas quam ruri, quando ad villam veneris./sed hoc etiam pulchrum est praequam ubi sumptus petunt/stat fullo, phyrgio, aurifex, lanarius;/caupones patagiarii, indusiarii,/flammarii, violarii, carinarii;/stant manulearii, stant murobatharii,/propolae linteones, calceolarii;/sedentarii sutores diabathrarii,/solearii astant, astant molocinarii;/[petunt fullones, sarcinatores petunt;]/strophiarii astant, astant semul sonarii./iam hosce absolutos censeas: cedunt, petunt"/treceni, cum stant thylacistae in atriis/textores limbularii, arcularii./ducuntur, datur aes. iam absolutos censeas /cum incedunt infectores corcotarii,/aut aliqua mala crux semper est, quae aliquid petat (505-522). Furthermore, through exaggerated satire, it expresses the thoughts of many Romans with regard to this situation. García Jurado (1993, 42, n.6) reminds us that we can find similar expressions in other works of Plautus in which "women adorned with estates" are mentioned or of Propertius, who talks about matrons "dressed in the inheritance of their grandchildren".

References to this other "mundus" of women; that of patrimony, or rather, of wealth, are numerous and although some may be very subjective and others blatantly misogynous, the fact is that they reveal the existence of what, in Rome, was considered a problem (Cortés Tovar, 2005, page 144): very rich women spending large amounts of money. If we go by the set of rules adopted in relation to these issues (basically sumptuary laws) it is difficult to determine what was more worrying to the roman of that period; the fact that there were a lot of rich women or the ostentation which accompanied this wealth. 
Pomeroy states that the $2^{\text {nd }}$ century B.C. "was a period of growth in terms of wealth and luxury among the upper classes, both for women and men" and cites the case of Emilia, mother of Cornelia and grandmother of the Graco brothers (Pomeroy, 1990, page 18). Was this ostentation more scandalous in the case of women? The lex Voconia (169 B.C.) appears to be a drastic attempt to put an end to the problem; it was no longer a case of forbidding the exteriorization of luxury, but to limit the rights of women to inherit under a will from first-class citizens, that is, those with the most power, through a measure directed specifically at restricting the flow of property to women.

However, the wealth of some women was a fact that could not be reversed and rich women continued to exist: during the Triumvirate period (42 B.C.) an attempt was made to force the richest roman women to allow their assets to be valued for fiscal and accounting purposes. The rapid response which followed led to a considerable reduction in the quantity of subjects affected- only 400 of the initial 1400 women were finally required to comply with the measure- (Cantarella, 1991, page 42). The application of the lex Voconia had also been evaded by the patres familias themselves through a variety of means so that, in spite of the legal requirements, they were able to leave part of their assets to their daughters (Castresana, 1993, page 77ff and Castresana, 1991, pág. 59). In fact, roman women of the upper classes had long-since distanced themselves from the domestic chores and duties, abandoning one of the traditional feminine virtues; domiseda, with the exception of their children's education, which was the family task they supervised. Otherwise, from the $2^{\text {nd }}$ century B.C. onwards, the vast majority of women pursued a life outside the home, either with or without their husbands. They probably won the battle for a reality which was often not necessary to fight for: they found themselves with plenty of money and few men. The legislative restrictions placed on women along with a social morality for both sexes which was based on civic virtues and principles opened an escape valve for the economic wealth, although, as previously mentioned, it was not sufficient (a summary of what the roman woman was able or not able to do can be found in (Rantz, 1982, page 280).

For this reason also, the protests by roman women which are known to have occurred, on the one hand, in favour of repealing the lex Oppia approximately fifteen years after it was passed ( supporting the Fundanius and Valerius tribunes), and on the other, against the edict of the aforementioned triumvirate in 42B.C., were motivated by economic factors or social status. Political inequality was taken for granted and unquestionable, even among women (Cortés Tovar, 2005, page 209). Furthermore, men shared a firm belief in the extraordinary frivolity of women, the weaker sex by nature, "abandoned, subject to their whims and to the passions of others" according to Tacitus, Anales, III, 34, in a reference to the lex Oppia. Cantarella points out that in the year 42, women refused to contribute to military spending if they were excluded from public life (Apiano, Guerras civiles, 4, 32-33), deploying the same argument used years before by the Valerius tribune to repeal the lex Oppia, claiming a sort of "right to success" for women, manifested by wearing jewellery which reflected their status, in the same way that men would assert theirs by publicly exercising magistracies and other honors (Cantarella, 1991, page 39 and 42).

The existence of women's factions or political groups-axitiosae- has been mentioned by a number of authors. Varro defined axitiosa as "activists" (Cantarella, 1996, page 86ff ) although García Jurado proposes a different sense to the term, translating it from the texts of Plautus as "capricious women", which fits in with the satirical aspects of his work (García Jurado, 2004, page 293ff) and which would appear to be fairly convincing if we consider the available information as a whole. In any case, it did not seem that women were asking to enter the men's world; this situation was taken for granted and not attacked. In the episodes recounted, political rights were not being demanded but rather, a return to the economic status quo which at certain times was at risk, in other words, the objective was to avoid changes to their "mundus". It took fifteen years to repeal the lex Oppia; there was no opposition from women to the lex Voconia as far as we know (perhaps, as mentioned previously, because its application was evaded via other legal mechanisms) and although the measures of 42B.C. were adopted, the number of taxable subjects was reduced.

Consequently, upper-class roman women lived according to their insignia-non magistratus nec sacerdotia nec triumphi nec insignia nec dona aut spolia bellica iis contingere possunt: munditiae et ornatus et cultus, haec feminarum insignia sunt, his gaudent et gloriantur, hunc mundum muliebrem appellarunt maiores nostri, Livy, XXXIV, 7, 8-, in their mundum muliebris, which is that of personal hygiene, grooming, jewellery and dresses (García Jurado, 1993, pages 44-45). Wealth should also be included. Were they satisfied with it? Did they not wish to gain admittance to other "mundus"? 
We know enough about the education of women to be able to affirm that after the initial years, in which they received basic instruction in moral values aimed at shaping the character of sons and daughters alike, more specific education was provided at school (also mixed) or by private tutors if the family could afford them. The instruction was principally concerned with reading, writing and arithmetic (Cid López, 2001, pages 31-37). In general, the paths of men and women separated at the age of twelve (Polo Toribio, 1998, pages 169-177) and in the sphere of education, this meant the end of schooling for women, whereas the men, who were still considered prepubescent, continued their instruction in grammar, mathematics, philosophy and rhetoric (Cid López, 2001, pages 35-36).

Nevertheless, the literature concerned with this subject repeatedly reports that women continued to receive instruction as normal (Hemelrijk, 2004) and at no time was education for women prohibited (Pomeroy, 1990, page 193ff). Many were not in favour of this instruction and this was evidenced by their criticisms of women who flaunted their knowledge. Others, however, praised it and would have welcomed a larger number of educated women (Francia Somalo, 2001, pages 51-53 and 62ff) and (Castresana, 1993, pages. 87-88). We know that women had their say, that they exerted their influence (or at least tried) in politics, although almost always by indirect means (Cid López, 2005, pages 167-168), commonly via the wives of emperors (del Castillo, 1976, pages 167-240). At a more day-to-day level, the letters of Plinius the younger reveal that friendships with women were used as "a key to gain something from or give something to a man" (Posadas, 2008, page 105). On other occasions their influence was more direct, such as supporting the repeal of the lex Oppia or their stance against the edict of 42B.C. although these were not the only cases. For example, the political graffiti found in Pompeii, through which women (putting their names to their work), advocated or supported a candidate, can be interpreted as an attempt to exert their influence given that they were not allowed to vote. In all likelihood, this kind of electoral propaganda would have been permitted because in the eyes of those in power, such meddling would have been considered petty. As Weeber points out, this graffiti would normally have been created by women who were close to the candidate and would never have contained any elements of feminist activism (Weeber, 2007, page 43ff).

On the subject of graffiti, the amatory inscriptions also reveal the degree of sexual freedom of many Romans. Literary sources from the period portray the sexual life of many women during the last centuries of the Republic. Although some of these sources pejoratively describe the promiscuity and involvement in other condemnable acts -abortions-, thus endangering the principles and virtues of Romans and hence, the Republic (Juvenal, Martial, Ovid), others contemplate love for a woman in a way that has become a literary and pictorial reference over the centuries; the love of Catullus for his Lesbia, which takes us far away from the roles of submission or sexual repression of women. Moreover, Lesbia does not seem to have been an exception.

By the end of the Republic, the model of the woman underlying roman society had all but disintegrated: the strength of character, the love of domesticity, the sense of shame, the decorum and austerity were things of the past, as was the ciues model of the roman man. The Republic itself was also a far cry from the model Republic.

\section{AUTHOR INFORMATION}

Alicia Valmaña Ochaíta, Degree in Law by University of Alcalá (Spain) and PhD in Law by University of CastillaLa Mancha (Spain). Associate Professor at Roman Law (Public Law and Legal Science Department). Faculty of Legal and Social Sciences of Toledo. University of Castilla-La Mancha (Spain). E-mail: Alicia.Valmana @uclm.es.

Research Interest: Democracy. Democratic reforms in voting district in Rome. Contracts in Roman Law. Ownership in Roman Law. Language and Law.

\section{REFERENCES}

1. Agati, E. M. (2004): "La lex Oppia y la condition juridique de la femme dans le Rome républicaine". Revue Internationale des Droits de l’Antiquitè (LI), 87-99.

2. Cantarella, E. (1991): La mujer romana. Santiago de Compostela: Servicio de Publicaciones e Intercambio Científico de la Universidad de Santiago de Compostela.

3. Cantarella, E. (1996): Passato Prossimo. Donne romane da Tacita a Sulpicia. Milán: Feltrinelli. 
4. Castresana, A. (1991): "Algunas observaciones sobre la condición femenina en Roma". Seminarios Complutenses de Derecho Romano (Vol. 3, págs. 53-60).

5. Castresana, A. (1993): Catálodo de Virtudes Femeninas. (De la debilidad histórica de ser mujer versus la dignidad de ser esposa y madre). Madrid: Tecnos.

6. Cid, R. M. (2005): Clodia imaginada por Cicerón. La construcción de la biografía de una libertina. En Pedrgal, \& e. González, Venus sin espejo. Imágenes de mujeres en la Antigïedad clásica y el cistinanismo primitivo (págs. 163-184). Oviedo: KRK.

7. Cid, R. M. (2001): La educación de la niña romana: de puella a matrona docta. En Alfaro, \& e. Francia, Bien enseñada: La Formación Femenina en Roma y el Occidente Romanizado (págs. 20-45). Málaga: Atenea.

8. Cortés, R. (2005): Espacios de poder de las mujeres en Roma. En J. c. Nieto, Estudios sobre la mujer en la cultura griega y latina (págs. 193-216). León: Universidad de León.

9. Cortés, R. (2005): Indignación satírica contra las mujeres romanas y sus pasiones: la misoginia en Juvenal. En Pedregal, \& e. González, Venus sin espejo. Imágenes de mujeres en la Antigüedad clásica y el cristinanismo primitivo (págs. 139-160). Oviedo: KRK.

10. Culhman, P. (1982): "La Lex Oppia". Latomus (41), 786-793.

11. D’Ambra, E. (2007): Roman Women. Nueva York: Cambridge University Press.

12. Del Castillo, A. (1976): La emancipación d ela mujer romana en el s.I d.C. Granada: Universidad de Granada.

13. Francia, R. (2001): La mujer romana y los ideales de la humanitas. En Alfaro, \& Francia, Bien enseñada: la formación femenina en Roma y el Occidente romanizado (págs. 45-68). Málaga: Atenea.

14. García, F. (2004): Axitiosae (Varro, Ling.VII 66):¿Activistas, Extravagantes o Caprichosas’?Sobre los avatares de una interpretación léxica. Emérita, 72 (2), 287-300.

15. García, F. (1994): "La moda en la antigüedad romana". Estudios Clásicos , XXXVI (105), 63-80.

16. García, F. (1993): "Las críticas misóginas a las matronas por medio de las meretrices en la comedia plautina". Cuadernos de Filología Clásica. Estudios Latinos (4), 39-48.

17. Hemelrijk, E. A. (2004): Matrona Docta. Educated women in the Roman élite drom Cornelia to Julia Domna. Londres: Routledge.

18. Pociña, A., and López, A. (1977): "Ovidio, 'Cosméticos para el rostro femenino’; introducción, revisión del texto, traducción y notas". Suplementos de Estudios Clásicos. Tercera Serie de Textos. (1), 1-27.

19. Polo, G. (1998): "Edad y Capacidad para Testar. Evolución Histórico-Jurídica". Actas del IV Congreso Iberoamericano de Derecho romano (págs. 169-177). Orense.

20. Pomeroy, S. B. (1990): Diosas, Rameras, Esposas y Esclavas. Mujeres en la AntigÚedad Clásica. Madrid: Akal.

21. Posadas, J. L. (2008): "Clientelas y amistades femeninas en Plinio el Joven". Studia Historica. Historia Antigua (26), 87-105.

22. Rantz, B. (1982): "Les droits de la femme romaine tels qu'on peut les apercevoir dans le Pro Caecina de Cicéron". Revue Internationale des Droits de l'Antiquitè (29), 265-280.

23. Weeber, K. W. (2007): Le Campagne Elettorali nell'antica Roma. Sant'Oreste RM: Apeiron. 


\section{NOTES}

